\title{
Insurance Business in Nigeria: A Solution to the Non Payments to Beneficiaries after Retirement
}

\author{
Bunu Mallam Abubakar, Mohammed Amin Umar \& Mohammed Alhaji Audu \\ Department of Private Law, University of Maiduguri P.M.B 1069 Maiduguri, Borno State, Nigeria \\ Department of Private Law, University of Maiduguri P.M.B 1069 Maiduguri, Borno State, Nigeria \\ Department of Finance, University of Maiduguri P.M. B. 1069 Maiduguri, Borno State, Nigeria
}

\begin{abstract}
The nonpayment of retired workers benefit has become the major problem affecting the proper functioning of civil servant as well as private sector workers. Efforts by successive governments to make the insurance reforms to work in the country have proved abortive. Recently however, the present leadership of the country is working on insurance Reform Bill. This is a welcome development which many believe will enhance the insurance system in the country their by benefiting the Insured as well as the national economy. This research work shed more lights on different aspects of insurance which must be taken into cognizance if this present planned reform must work optimally. These include: function of insurance, stakeholders in insurance, registration, compliance and benefit of insurance. The crucial role that the Nigerian Insurance Company plays in the success of insurance in the country is also highlighted.
\end{abstract}

\section{Introduction}

Insurance business is an important business that exists to keep other business alive. The issues pertaining to insurance business in Nigeria has been a concern for many writers. Insurance business is one of the businesses that have a profound impact on virtually all aspects of life and living. The insurance industry is a service oriented industry that helps individuals and corporations manage the risks inherent in living and business activities.

\section{Definition Of Insurance}

The business of Insurance has grown so complex over the years that no single definition can cover all its many branches. The word insurance has several definitions by various authors.

${ }^{[1]}$ Posited that insurance is an arrangement for transferring and distributing risk. It is an arrangement under which one (called insurer) contracts to do something that is of value to another (usually called insured but sometimes called beneficiary) upon the occurrence of a specified harmful contingency.

${ }^{[2]}$ Defined insurance as a contract whereby one person called the "Insurer" undertakes in return for the agreed consideration called the "premium", to pay to another person called the "Insured" a sum of money or its equivalent on the happening of a specified event.

${ }^{[3]}$ also defined insurance as any contract whereby one party assume the risks of an uncertain event which is not within his control happening at a future time in which event the other party has an interest, and under which contract the first party is bound to pay money or provide its equivalent if the uncertain event occurs.

The purpose of insurance is to spread a loss. And this is because insurance is to spreads the economic burden to losses by using funds contributed by members of a group. While it is not possible to do so, that is to eliminate the loss, it can soften the blow by offering some financial compensation.

\section{Functions Of Insurance}

The functions of insurance are divided in two (2) folds, that is the primary functions and the secondary functions.

\subsection{Primary Functions}

At common law the primary function of insurance is to ensure that the financial losses of the insured are fairly equitably distributed. The insured or otherwise known as the policy holder pays premiums into a common pool, out of which the unfortunate few who suffer losses will be compensated. The purpose of insurance is to compensate or indemnify the victims for his financial losses. Insurance neither eliminates the loss nor does it undertake to stop the misfortune or disaster from happening. All it does is to help soften the blow from purely economic view point. Thus, the fact that the bread winner in a family has been wise enough to have taken out a life policy would not prevent him from dying in a motor accident but proceeds life policy which is payable to the dependents help lighten their burden of the demise of the bread winner. 


\subsection{Secondary Functions}

The insurance industry provides a good number of secondary services which are of immense value to the community, these are;

1. Insurance releases funds which would have been otherwise tied down; this is because no prudent industrialist would consider investing large sums of money in a project without some suitable safeguards. In the absence of insurance these sum of money might be a substantial reserve fund so that misfortune would not bring financial loss, but with insurance the funds is released and this leads to the promotion of trade and hence employment.

2. Insurance serves as a means of saving, most people find it difficult to save, but insurance policy is often a very suitable way of providing for future needs. This type of policy is particularly found in life insurance.

3. The money contributed by policy holders in a form of premium over a long period of time is invested in industries and a number of allied enterprises and this allows for economic growth of the country.

4. Insurance helps in enhancing export and import trade. For instance, the danger of ships sinking or getting loss in a sea is frightening to many potential importers and exporters but with the aid of insurance it is well covered to undertake the trade.

5. Insurance as a risk transfer mechanism provides a cheap means of handling risks to the insured in view of the fact that the principle of large numbers is brought to bear in the practice and operations of insurance.

6. Insurance allows the management of an organization to concentrate on the other aspects of management as against thinking of how to cope with losses from insurable risks.

7. Insurance business contributes to the earning of foreign exchange as an invisible item on the balance of payment account of a country.

8. Insurance prevents and control loss through the conduct of surveys e.g. fires, theft surveys and factory inspections and recommendations on risks management.

\subsection{Stakeholders Of Insurance}

The stakeholders of insurance industries are divided into (2) two, they include;

1. Individual stakeholders

2. Institutional stakeholders such as PFA, PFC, NICON etc.

\subsection{Individual Stakeholders}

Individual stakeholders (the people involved in policy making) come from within and outside the government. A stakeholder is an individual that makes a difference or that can affect or be affected by the achievement of the organizations objectives such as policy making objectives. Public sector individual stakeholders can include politicians (head of state and legislators) government bureaucrats and technocrats from various sectors e.g. health, education, finance, local government and public sector staff who implements programs. Stakeholders from nongovernmental sector can include representatives from civil society organizations, support groups or faith-based organizations. They can be researchers and others such as media personalities, individual beneficiaries of policy can also be involved in calling for policy change.

\subsection{Institutional Stakeholders}

Institutional stakeholders include Pension Fund Administrators, Pension Funds Custodians, Nigeria Social Insurance Trust Fund, National Insurance Corporation of Nigeria (NICON).

\section{6 contributions of nigeria social insurance trust fund as institutional stakeholders}

The NSITF have contributed by alleviating the suffering of old age or due to invalidity of unemployment, due to retirement. The monthly contributions collected from various employees are invested. Each contributor to the scheme have an account to which the amount contributed by him/her is credited. Also credited to individuals account is the interest due.

The function of the scheme is organized by the pension fund administrators through schemes of arrangement as follows;

1. Registration

2. Compliance

3. Benefits

\subsection{Registration}

This section of the scheme is responsible for funding these organizations that under the decree are liable to register i.e. those employees of labour with ten workers above. Apart from registration, the employees are also provided with basics for completion for employee, for subsequent registration. This function is decentralized to all officers so as to avoid any delay in registration. 


\subsection{Compliance}

This section of the scheme is solely responsible for collection of monthly contributions from the employers. In practice, the unit awaits the employers to bring the contributions. Target is given to each staff and the employer is allocated to various staff for the monitoring of their contributions and this is due for collection at the end of every month.

\subsection{Benefits}

These section has the responsibility to carry out the objectives of the fund or the scheme i.e. payment of benefits to the deserting members in the event of occurrence of any of the following without any delay.

a. If the contributor of a foreign nationality is living Nigeria for good.

b. If the contributor attains or reach the age of 60years or 35 years in service.

c. A good contributor becomes invalid through accident or such calamities made him/her disable for good.

d. Upon death of a contributing member.

It should be noted that all the above claims are once and for all. It is hope that the lump sum paid will help to reduce the suffering of the contributor after either retirement or otherwise officially.

\section{National Insurance Corporation Of Nigeria (Nicon)}

The objectives of this insurance scheme (NICON) is basically concerned with getting the right people, in the right number, with the right knowledge, skills and the experience, in the jobs, in the right place at the right time and cast ${ }^{[4]}$. NICON has always devoted manpower for planning. The corporation has been able to avoid unnecessary resort to such unsavory steps as natural wastage voluntary or compulsory redundancies, dismissal freeze on recruitment, work sharing; ban on overtime, early retirement, which in NICON are considered as undesirable panic measures which should have been eliminated. Besides, there is NICON tradition of training and development of their employees. NICON training activities is focus on acquisition of skills at different level in the organization such skills includes technical, conceptual, supervisory, human relation etc. in specific areas of management activities.

\subsection{Pension Funds Custodians}

According to ${ }^{[5]}$, Pension Fund Custodians (PFC's) will be responsible for the warehousing of the pension funds assets. The pension funds administration shall not be allowed to hold the pension funds assets. The employer sends the contributions directly to custodians, who notifies the pension funds administrators of the receipts of contributions and the pension funds administrators subsequently credits the retirement savings account of the employee. The custodian will execute transaction and undertake activities relating to the administration of pension funds investments upon instructions by the pension funds administrators. The custodian shall hold pension fund assets on trust for its clients. For the same reasons adduced in the case of the pension funds administrators. A stakeholder of the custodian must be a licensed financial institution and having a minimum net worth of $\$ 5,000,000,000$ and a total balance sheet of not below $\$ 125,000,000,000$. The shareholders of a custodian must guarantee the pension fund assets held by it.

\subsection{Functions Of Stakeholders And Government}

Insurance companies have played a vital role in economic development of Nigeria. Therefore, one of the indices for measuring the development of an economy is the size and maturity of its insurance company ${ }^{[6]}$. This is because insurance play a very important role in the mobilization and utilization of investable resources in the economy. It also acts as an absorber with economic activities, the absence of a market for which can greatly reduce the growth of economic activities.

The insurance companies have been playing a very useful role in the economy, most notably in the following areas:

1. Reduction of the out flow of resources from the country through the retention of insurance and reinsurance premium within the economy, with a positive effect on the country balance of payment.

2. Development of capital market: the insurance industries constitute one of the major institutional investor in the capital market, thereby providing a channel for sourcing of funds both to the public and private sectors of the economy.

3. Cultivation of insurance consciousness, the advent of the organized insurance industry and the activities of its stakeholder have greatly improved the cultivation $f$ insurance consciousness among business owners and individuals. This has reduced the level of risks, which generally encourages entrepreneurship and therefore enhances the growth of the economy.

4. Direct equity and loan insurance in industrial enterprises. The industry is a major catalyst in the development of the large industrial undertaking, which are highly capital incentives. 
5. Mobilization of savings: the activities of the industry particularly life assurance business have encouraged the mobilization of saving which otherwise may not have been channeled to any production, such mobilized savings constitutes an important source of long term investable fund in the economy.

\section{Benefits Of Insurance}

Life insurance provides the dual benefits of savings and security. The following benefits explain why this investment tool should be an integral part of your financial plans.

- Risk cover: life today is full of uncertainties; in this scenario life insurance ensures that your loved ones continue to enjoy a good quality of life against any unforeseen events.

- Planning for life stage needs: insurance does not only provides for financial support in the event of untimely death but also acts as a long term investment. You can meet your goals, be it your children education, their marriage, building your dream home, or planning a relaxed retired life, according to your life stage and risk appetite.

- Protection against rising health expenses: life insurers through riders or stand alone health insurance plans offer the benefits of protection against critical diseases and hospitalization expenses, this benefits assumes critical importance given the increasing incidence of life style diseases and escalating medical costs.

- Build the habits of thrift: life insurance is a long term contract where as a policy holder; you have to pay a fixed amount defined periodically. This builds the habits of long term savings. Regular savings over a long period ensures that a decent corpus is built to meet financial needs at various life stages.

- Safe and profitable long term investment: insurance is a highly regulated sector. IRDA, the regulatory body through various rules and regulations ensures that the safety of the policy holder's money is the primary responsibility of all stakeholders. Life insurance being a long term savings instrument, also ensures that the life insurers focus on returns over a long term and do not take risky investment decisions for short term gains.

- Assured income through amities: An insurer is one of the best instruments for retirements planning. The money saved during the earning life span is utilized to provide steady sources of income during the retired phase of life.

- Protection plus saving over a long term: since traditional policies are viewed both by the distributors as well as the customers as a long term commitment, these policies helps policy holders meet the dual need of protection and long term wealth creation efficiency.

- Growth through dividends: traditional policies offer opportunities to participate in the economic growth without taking the investment risk. The investment income is distributed among the policy holders through annual announcement of dividend/bonus.

- Facility of loans without affecting the policy benefits: policy holders have the options of taking loans against the policy. This helps you to meet your unplanned life stage needs without adversely affecting the benefits of the policy they have bought.

- Tax benefits: insurance plans provide attractive tax benefits both at the time of entry and exit under most of the plans.

- Mortgage redemption: insurance acts as an effective tool to cover mortgages and loans taken by the policy holders so that, in case of unforeseen event, the burden of payment does not fall on the bereaved family.

\section{Political Aspect Of Insurance}

1. Political violence, such as revolutions, insurrection, civil unrest, terrorism or war.

2. Government expropriation or confiscation of assets.

3. Governmental frustration or repudiation of contracts.

4. Wrongful calling of letters of credit or similar on demand guarantees.

5. Business interruption

6. Inconvertibility of foreign currency or the inability to repatriate funds.

\section{Reference}

[1]. Robert E. Keeton (1971) Insurance law basic text, west publishing company Pg. 2

[2]. Hardy F. R. Ivamy (1986): General principles of Insurance law, fifth edition. Butterworth and CO. publishers' ltd. Pg. 1-12

[3]. John Birds (1988): Modern Insurance law, second edition, sweet publishing and printing company Lagos Pg. 1-12

[4]. A publication of NICON Insurance Plc (1994): NICON at 25, Sahel publishing and printing company, Lagos Pg. $1-12$

[5]. The chartered Insurance Institute of Nigeria (1999): Insurance Agents Certification Workshop. Pg. $2-6,3$ and 11.

[6]. Saleh Galadima (1982): the role of NICON in Nigeria's economic development Pg. 4. 